\title{
Organic Intelligence: Walking, Living, and Attuning Systems
}

\author{
NATHANIEL STERN \\ University of Wisconsin-Milwaukee \& University of Johannesburg
}

\begin{abstract}
Mauritian-born architect and activist Doung Anwar Jahangeer's failed attempt at suicide resulted in a new life of walking and talking, teaching and learning, between his habitat and communities. Vulnerability: an openness to power, beliefs, agencies, languages, meanings, relationships, or struggles outside our standard spheres of movement; such an openness can of course lead to damage, but it might also lead to wonder, creation, or love (Bakhtin, McKay, Garvey, Brown). In the face of what felt like overwhelming powerlessness, Jahangeer began moving around, and listening and attuning to, the potentials of life outside the limits he and his habitat had constructed to that point.
\end{abstract}

\section{AFTER MULTIPLE ATTEMPTS AND FAILURES TO GET INTO ARCHITECTURE GRADUATE SCHOOL WITH RESEARCH PROPOSITIONS VERY CLOSE TO HIS HEART, DOUNG ANWAR JAHANGEER WAS FEELING, LITERALLY, SUICIDAL.}

Jahangeer made two attempts at taking his own life, but was, thankfully, bad at committing the final act. He eventually decided to seek assistance in bringing about his own demise. Jahangeer took his expensive digital camera and began walking in Durban, South Africa-the city where he lives-down a path that was known for crime and violence. This was somewhere he was told never to go if he wanted to remain safe. Perhaps, Jahangeer thought, he would be robbed, hurt, and left for dead. Crime-related homicides are not an uncommon occurrence in that part of the world.

Jahangeer eventually stumbled near a young man who eyed his imaging equipment with obvious thirst in his gaze. Jahangeer told me, via Skype, "So I walk in with my camera and as I walk in, somebody says, 'Ey!' You know? And I thought, that's it." Several seconds passed, and he waited for the violence he was sure would come from his would-be attacker. "So I freeze and he calls at me, 'Ey you!' So I look, and he says, 'Come here.' So I go towards him ..." The two men-one black South African obviously confident in his surroundings, and one suicidal and out-of-place architect of color with difficult-to-know originsjust stared at one another for what seemed like an eternity of strange, strung-together moments. "He looks at me, and he says, 'Shoot me!'” [1]

Jahangeer pauses for a moment here, then goes on, "Now, I couldn't believe what I was hearing. He says, 'Shoot me!'” Jahangeer instinctively knew that there had to be more here than what he was seeing and feeling, more than what the narratives of South African violence portrayed for him up until this moment. "Because it was nothing like what everybody for the past five years has been telling me about 'those people.' You know?" [1] He began to wonder in much broader contexts, What is this encounter truly about? What did the young man facing him want? What did he want from Jahangeer, and also what did he want more generally? Jahangeer was both intrigued and bewildered.

"And as I bring the camera to my eyes, you know, and I'm just holding it there, I don't know what to do, you know, I couldn't click ... against all of these kind of things coming in my head, and between the lens and that person, suddenly it was almost like I was humanized instead of being killed. That person that was supposed to kill me has given me my life back." [1]

This confrontation in February 2000 was a new awakening for the artist. A Mauritian-born, Muslim-raised Creole of Indian descent, Jahangeer has lived in "Zululand" on the east coast of South Africa for nearly twenty years, and traveled the world in between. But in this moment, he felt he knew nothing about the spaces around him. Here, where he was most vulnerable and expecting violence, came someone asking him to play, to make art and images, to do productive things, together.

Jahangeer went back home and moved from being depressed"extremely depressed"-to manic. [1; emphasis implied by tone] Could this be real? Did he remember it properly? He went back the next day, and the same man was there as if waiting for him, staring back from just off the path. Jahangeer learned his name was Sipho; they shared life stories, and drank beer "in the morning, which I had never done before in my life". [1] They became and are to this day good friends. And over time for Jahangeer, this and later similar walks became his higher education: spaces to search for, engage with, and talk about structures and relations-between people and places, or architecture and animals, muscles and movements, or blades of grass that literally slip and grow through the cracks of our built environments in order to spring free. Sipho implicitly and explicitly taught him to look more carefully at his habitat, and the roles he and others, and other stuff, play within it, and as a part of it. Jahangeer has met many friends on his walks, has so many interesting interactions with life and nonlife, people, things, and matters that he is always itching to talk about, and learn more from. 


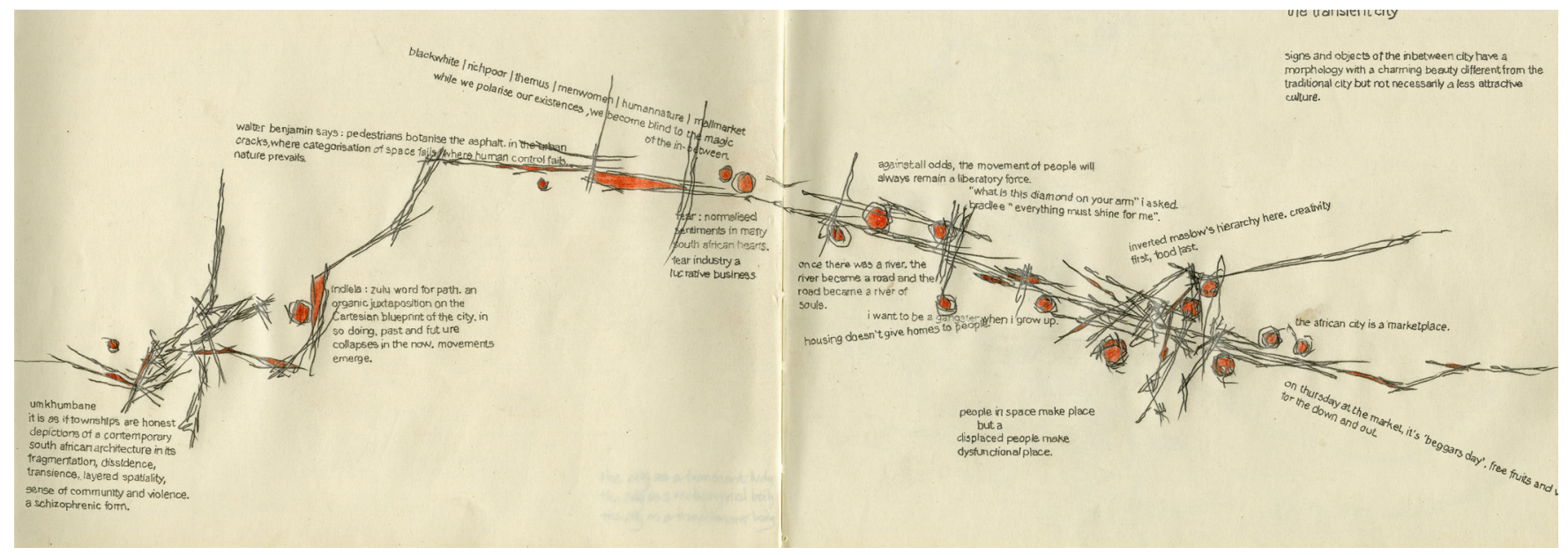

Figure 1: Transumancity, a map of Durban as a transient city, by Doung Anwar Jahangeer.

The walks, the stories, the encounters became an "obsession for [Jahangeer] to share." [1] He kept going back, kept walking and looking and thinking and feeling and socializing and engaging - and telling others all about it. And eventually, friends began asking if they could come along. It became "Doung's City Walk," a project, artwork, and experience where Jahangeer treats a walk through the city, and around the city, as an experience and practice of architecture and artfulness. He takes people with him on a performance-something performed, not pre-formed-and points out the paths that we take and the movements that we make, how they think and feel and shift and move, together. Each walk is an opening to relation: social, natural, personal, political, architectural ... Jahangeer highlights how each of these categories transversally affects us and the world around us, so much more than we would like to admit.

There are many walks - "the proper one, or the original one [in Durban], which starts from a bourgeois suburb to the market. And then there is from the township to the market again," and many more, all over the world-but no matter what, every walk is different. It is "profound . . . the role that the gaps, the absence, the in-betweens [play] in defining "polarities'" between people and things, that are not actually opposed, according to Jahangeer. [1] These separations are closer, I argue alongside the artist, to boundary projects. It is our difference, along with our contact and relation, that make us what we are. And Jahangeer's walks heighten our awareness to those inside-outside-insides-outside.

Jahangeer does this on both large and small scales. Here is some of Oscar Hemer's experience, worth citing at length:

"I joined him on his five-hour tour from Musgrave shopping centre in a predominantly white inner-suburb [following] the heavily trafficked N3 freeway, on a parallel pedestrian highway with scattered sweets and cigarette vendors. We make a short cut through an area of deserted apartment blocks where the homeless, some months before, had managed to chase away the drug lords, only to be brutally evicted back onto the street by the police. We arrive at the Warwick Triangle, the true heart of Durban: a conjunction of crossing freeways, a railway terminal and a taxi-rank where more than half a million people pass every day. I have passed it close to a hundred times by car or taxi on my three visits to Durban, but never on foot-and it is truly a completely different experience. The passage has become a bustling market place. The air is thick with petrol and diesel fumes, scents of herbs and dried animals in the medicine stands, and the nauseating odors from the food-tents where cow-heads are being axed and boiled. There is also an almost palpable tension in the air. I, as a white, am obviously out of place. This is a non-place, invisible from a car's window, and consequentially these are non-people. Even South African tourist guides warn visitors to the nearby Victoria Street Market never to go beyond the limits of the Market building.

Walking the street of Durban becomes a revelation: it changes my entire perception of the city and of South Africa as a whole. I discover things I never saw before, and I move with a new sense of casualness." [2]

Hemer makes explicit what Jahangeer implies in his story: contact and difference, race and power, history, present, and potential futures, are all kept in place by our built environments. But, according to Jahangeer, these environments are "transient and shifting, rather than concrete and absolute," even when they are, literally, concrete. [3] These structures can be, and are always being, disrupted. Jahangeer asks us to wonder at creepers slowly overtaking barbed wire, at houses as poetry, at urban landscapes as musical compositions, at cow-head markets and "dangerous" paths as places to make friends ... at how all of these foster or inhibit how it is we inhabit our cities, friendships, selves.

Looking back, Jahangeer believes his ability to see again was delivered only because of his vulnerabilities, his openness to big change without fear. While vulnerability is often thought 


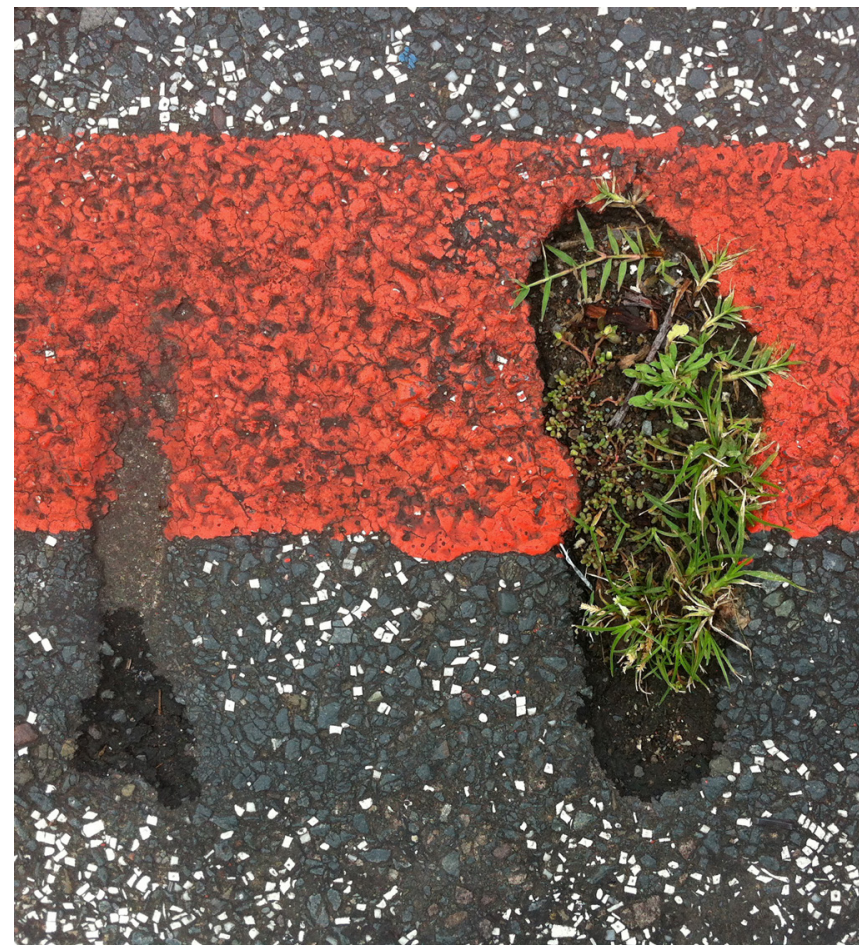

Figure 2: Botanizing the asphalt, CityWalk logo, by Doung Anwar Jahangeer.

of in negative terms, especially in relation to animals, bodies, and ecology [4], art and architecture education scholar Sara Wilson McKay takes a slightly different approach. Following and building somewhat on Mikhail Bakhtin's study of language, she encourages "an open attitude toward vulnerability" so as "to emphasize ... social possibilities through art." [5] Although vulnerability is not a word Bakhtin uses directly, literary and cultural scholar T. Gregory Garvey asserts that Bakhtin promoted a kind of "empowerment" through recognizing, and reorienting ourselves around, the "contradictions" in "multiple and internally variegated languages [and] contexts" in the world. [6][7] The example Bakhtin gives is of a "peasant" who "lived in several language systems" at once: at church, in song, with her family, at work, or with the local authorities, for example. And here our peasant-heroine easily moves between these language-meaning spaces without a second thought.

When this heroine is "able to regard one language ... through the eyes of another language," however, everything changes. She recognizes that these are not only different languages, but different ideologies, different approaches, which inherently contradict one another and can "in no way... live in peace and quiet with one another." [7] Bakhtin uses the term heteroglossia to describe this situation. In the everyday, heteroglossia means multiple voices, meanings, or expressed viewpoints in a single word, text, image, or artwork. For Bakhtin, everything should be considered through these multiplicities; there is value in opening ourselves up to, and navigating in and around, active and varied meaning-making processes.
The pauper's empowerment comes with opening herself up to contradiction, and actively choosing how to move between them.

Postrevelation, Garvey somewhat cynically promotes our heroine's new ability to "mask" herself, or "carnivalize and subvert authority." She cannot "escape the ideological dimension of discourse," but can navigate in and around (power) structures and meaning-making, which, I continue, are both active, and in relation, across different spaces and contexts. Both Garvey and McKay say that Bakhtin strives "to understand communication not by analyzing language, but by analyzing how selfhood and intersubjective relationships are structured and mediated by communicative action." [8] According to Bakhtin, the structures of dialog, meaningful exchange, and interconnectedness-what he calls intersubjective actions, with/between subjects-and-subjects (rather than from subjects to objects) - are a necessary part of being and knowing, learning and acting. But while Garvey says the "value" in the "opacity" of language is "empowerment" and "autonomy," [8] McKay more poetically calls the "other" of "transparency" vulnerability. She asserts that "Bakhtinian dialogic subjects" require both transparency and vulnerability in their relationships, for new, and pedagogical, possibilities to arise. [9] We must be generous in how we attempt to communicate and relate, and vulnerable in how we look, listen, and see, to find more meaning(s).

Says McKay, more simply, "vulnerability is a necessary condition for seeing more." [9] "Researcher-storyteller" Brené Brown drives this point home, on a more personal level, when she says that while vulnerability is "the core of shame, and fear, and our struggle for worthiness," it is "also the birthplace of joy, of creativity, of belonging, of love." [10] This is precisely what Jahangeer learned on that fateful February day, and every day thereafter. Brown says that you cannot quarantine only one emotion, such as vulnerability, and so when Jahangeer opened himself up to the possibility of harm, he also welcomed creation and joy, understanding and reorientation, and a multitude of other possibilities and potentials in and as life.

McKay defines transparency as "metaphorical seeing through something that allows for ... revealed politics," and vulnerability as "exposure and openness" to such things. [9] The former encompasses an individual desire to engage with others in their own languages, and the latter acknowledges "the limits of our seeing (knowing)" in our own languages. She says that the best of art (and architecture) "cultivates a willingness to be vulnerable and to respect vulnerability in others, creates intersubjective possibilities [toward] significant change." [9] At rock bottom, at his most vulnerable, Jahangeer was completely and utterly open in a way he had never been before. Of course, this is not to say one needs to be suicidal to be open or vulnerable; on the contrary, Jahangeer's stories and walks-together might 


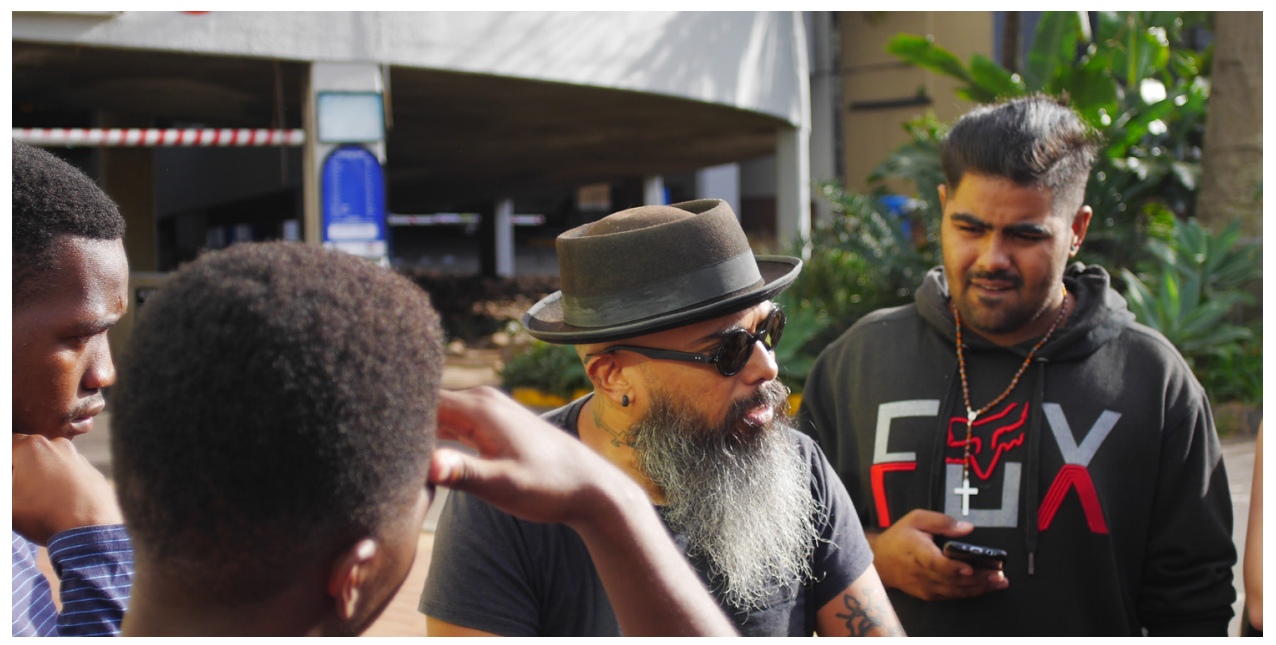

Figure 3: CityWalk 2017, with Doung Anwar Jahangeer in the center (with hat, glasses, and beard).

be enough to offer us a drive toward such engagements. But in that described moment, he forced himself into a new space and language, and responded to what could have been a "dangerous" request, rather than running away.

In the face of what felt like overwhelming powerlessness, Jahangeer began moving around, and listening and attuning to the potentials of life outside the limits he and his habitat had constructed to that point. Attuning: listening to and looking for, while amplifying and making, harmonies and resonances, chords and dis-chord, notes and music. And for Jahangeer, the potential for change through attunement came with walking the city while vulnerable. It came while moving. Moving in relation; moving the relation; moving-thinking-feeling with an attentiveness to, and concern for, everything but himself. That concern eventually came to be for the humans, nature, politics, and environments he is always contributing to and a part of but, until that moment, was rarely aware of. Jahangeer now knows he doesn't know his surroundings, his interconnections, himself and the roles he plays within them; but he yearns to play more, to learn and make, to take risks, regardless.

\section{THIS IS AN INTERESTING PREMISE TO BEGIN FROM, WHEN WALKING. HOW DO WE MAKE OURSELVES VULNERABLE TO OUR ENVIRONMENTS, AND EACH OTHER? WHAT DOES SUCH A THING ACCOMPLISH?}

According to French scholar Michel de Certeau, whom Jahangeer often directly references, walking any given city is always an intervention into the metanarratives generated by the strategies and structures of governments, corporations, and other institutional bodies. During apartheid, walking and various other forms of transit were highly regulated, and chance encounters between real and vulnerable people of different skin colors were obstructed. This was safer, better, more efficient, South Africans were told. And now in postapartheid South Africa, there are fewer laws, but no less explicit rules, around who belongs where, and when, and to what purpose. Jahangeer believes it is part of his job as an architect and activist to subvert such dominant paradigms of power, among them the legacies of apartheid-just as it was his job to subvert apartheid itself in past decades. Here "dominant paradigms" go beyond values, or systems of thought; they are shaped not only by a community's cultural background and the context of the historical moment, but also by current physical spaces and architectures-whether natural or constructed-and how we move through them.

In his well-known "Walking in the City," de Certeau starts in the (original) World Trade Center, viewing the totality of New York with a detached and distanced stance of scientific knowledge. Such is the intellectual, institutional, dominant, perhaps hegemonic view of life and the city. It is the supposedly objective perspective that allows dissection and observation without direct involvement. For Jahangeer, perhaps this was the view from where he wished to be, a graduate student studying from behind the safe walls of the academy in Durban. By instead making themselves completely vulnerable, by walking and writing a new story with the city and its inhabitants - rather than viewing and reading and implicitly "knowing" that which is outside-both Jahangeer and de Certeau replace totalitarian "facts" with specific and personal relationships; they replace metanarrative with micronarrative, objective distance with contextual place- and meaning-making. Whereas metanarratives attempt to provide a kind of overarching accounting for people's beliefs and actions (usually for those people), micronarratives give explicit context, accounting for what individuals do, and why. Jahangeer's walk did not see him facing an abstract, violent criminal, who easily fits within a stereotyped, political problem. Rather, Jahangeer now has in Sipho a potential collaborator for composing alternate stories, people, places, environments, futures...

Michel de Certeau would call Jahangeer's approach a tactic rather than a strategy, given how the former contrasts them in The Practice of Everyday Life, the book in which his "Walking the City" was first published. In the military, a strategy denotes the key campaign that works toward a main objective, such as winning a war and/or overthrowing a government. Tactics, 


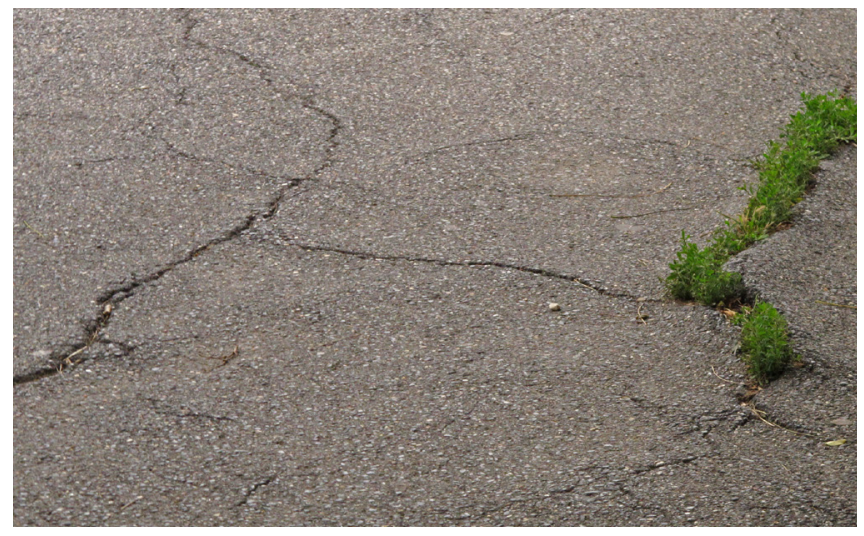

Figure 4: Dissidence, a walk in the park with Doung Anwar Jahangeer, 2003.

then, are the techniques applied to succeed in lower-level operations and are thus subordinate to strategy in such a context. In everyday life, however, de Certeau does not put tactics below strategy hierarchically, as the military does; rather, he sets them up as opposed.

Strategies, according to de Certeau, are always based on the presumption of knowledge and control. Governments and corporations, for example, are part of an "in-group" with power, who carry out campaigns to accomplish specific goals over time. These goals range from apartheid rule or urban planning for crowd control to the development of customers with new product lines through various forms of customer discovery and advertising. The obvious problem here is that the situations on which any strategy is based are always changing, thus that campaign is constantly becoming obsolete.

Tactics, on the other hand, are how those without power live in flux. They are our activities that constantly shift based on encounters and relations reassessed in, and as a part of, our lived environments. Rather than assuming how things will go and be, tactics see a kind of agility that takes advantage of unpredictability. Strategies must believe the fiction of stasis in order to move forward, and they are therefore undermined by changeincluding any movement that takes place because of their own success or failure. Tactics make an ally of change and movement; they are "the ingenious ways in which the weak make use of the strong." [11] They deploy, in a word, tact: a sensitivity to others and other things, to the world around us and how it changes, how it moves and is moved. Tactics mean both openness and agility.

Here de Certeau also looks to the identities of "producers" versus "consumers" in capitalist society. Consumption, he argues, is never consumption alone. Cultural consumers poach and appropriate from the supposed producers; they enunciate anew across social, political, and economic boundaries. In Jahangeer's case, his adopted path was actually never meant for walking. It is off the pavement, a walker-produced single lane of former plant life that has been foot-worn down to dirt. This path is difficult to see if you don't know to look for it, yet it is used by a whopping seven thousand daily commuters traveling between the township of Cato Manor and Durban's city center. "And they walk there to save some money, to buy food or stuff like that. And they remain a very invisible community of pedestrians in the face of the municipality and the system." [1] Even the pavement this path runs parallel to was originally intended as a freeway, not for walking. And that pavement is now where most of the off-street vendors reside, hawking their wares of fruit and vegetables, candy and cigarettes, cell phone chargers, and more. So while the city planning commission determined what streets there are and how they are meant to run, it is the locals who figure out how best to navigate the reality of those lived streets. In a system such as this, there is cooperation as much as there is competition between people and places and things.

Early on in his investigations, Jahangeer once decided to buy a loose cigarette as he walked and thought. He followed the flow of traffic, at a pace with his peers, and enjoyed his "loosey." Just as he finished and was about to throw his butt to the ground, another stand appeared in his path. Curious, Jahangeer bought another cigarette, lit it with what was left of the first, and kept walking. Again, just as he pulled his final drag, he came upon another vendor. He repeated his gesture, and it happened again. The vendors had self-organized, unbeknownst to them, at exactly a cigarette's distance apart.

Jahangeer calls such tactical choreographies "organic intelligence," a kind of emergent architectural life that organizes and adapts based on what is there, what is needed, what is wanted, and what can happen. The consumers of the path are the producers of how it functions, and these said-same producers are the consumers of space, and time, and savings, and cigarettes. They are, by the thousands, says Jahangeer,

"walking every day and every night back and forth. And their objective is to conduct their livelihood. They're saving five rand just to be able to buy a plate of onions or tomatoes so that when they get home, you know, they can have something instead of paying the taxi fare. And ... their practice of their livelihood has given rise to this ... energy where people support each other." [1]

Jahangeer's face is wonderfully and wondrously animated as he shares these stories with me on Skype, through our laptop screens; and I can easily imagine his body walking, moving, sharing, and gesticulating in much the same manner on one of his art experiences. He occasionally pauses to chat with one of his children, and similarly, on a ride through Zululand, we would of course be surrounded by the vigorous community he loves describing, and one that, he also says, forms a kind of collaborative resistance. Like the Million Man March, or Mahatma Gandhi's Salt March. Any walk outside the systems, strategies, and controls of government, corporations, and other powerful institutions, tactically (and tactfully) resists. 
This is the real city, alive. The city seen from above is an illusion. The one that walks, talks, reads, dwells, cooks, smokes, and overall, moves, is actual, actualized, and actualizing. The city is, architect and media theorist Reinhold Martin reminds us, a "thing" that is always "relative to the individual human body." Like us, cities "gather worlds around themselves. They socialize. They assemble. They differentiate as well as enfold humans and nonhumans." [12] They have memories, and thinkings, and feelings, and constantly shift their trajectories of becoming, with and around and against us.

We, and the city, are always temporary, vulnerable to ourselves and the outside. And this can be a good thing. Present vulnerability can also be understood as present capability, which creates future opportunity: always changing, adapting, becoming anew along with our habitats. We attune and shift, open up and take risks, accept transformation and keep moving.

\section{JAHANGEER, AT HIS MOST VULNERABLE, EMBRACED AN ECOLOGICAL APPROACH, AESTHETIC, AND PRACTICE.}

Jahangeer also told me about a walk he took in Mumbai several years before walking became an art practice for him. After traversing the crowded dirt and concrete streets, teeming with people and cars and bicycles-not to mention developing, DIY capitalism in the forms of vendors and car drivers offering deals and rides - he became utterly mesmerized by a single blade of grass that had managed to grow out of a minuscule crack in the pavement. This is something we see all the time, and that Jahangeer now points out as second nature, dozens of times, on any given walk. Yet it can be magical to behold. And it's everywhere. Grass will grow in the space between bricks, between the road and the pavement, in the unintended cracks that always, eventually, come, from the shifts of life and nonlife below. In fact, the grass itself plays a role in the cracking and breaking that makes space for it. Things find their way. If we only look and listen, we consistently see, and feel, animals and insects, plants and water, rocks and sneakers and bottles, where they "shouldn't be." New paths, literal and metaphorical, are paved by foot traffic and runoff, grass and rabbits, cigarettes and Coca-Cola. Jahangeer asks, How did they get there? And on his walks, he tells stories of what might have happened, opening up more of what still can ...

This, too, is a form of resistance. Jahangeer reminds us it is where the "infrastructure that we use to categorize space fails; at all those points you will see that nature will come out of that. Almost as if it is a sense of redemption." [1] Roads and asphalt, painted lines and signs, freeways and buildings and more: these are all built and coded to tell us how to move and not move, are all attempted strategies of control over us, our habitats, our encounters and relations. Jahangeer asks us to be open and vulnerable to the living systems outside that control. In other words, we are not asked to move in a specific way; we do not change who and how we are; but we experience and practice alternate styles of being and becoming. We change our manners with all manner of things. Here is a new aesthetic practice, and all that entails.

Jahangeer performatively, and literally, calls attention to the organic intelligence around us: the walking, living, and attuning systems that we are also always walking, living, and attuning to. He asks for tactful tactics, and the stakes are quite high. What is vulnerable, what will change, and how? Who is in control, and/or how does the illusion of control impact our activities? What strategies of power are at play? What tactics are deployed by the blade of grass, the walking path, that man, this cigarette? In every footprint, through every crack, across each transaction, there is potential for life and growth, violence or collaboration, new histories and substitute futures.

Jahangeer's practice of walking - the stories he both tells and unfolds, shares and asks for-brings together people and places and things and emergent forms of life, thought, and being. He calls for a doubled responsibility, in how we acttogether, and in how we re-present our activities-with the world. How can we be more organically intelligent, and intelligently organic? He ask us to artfully, vulnerably, tactfully, and tactically, move-together in what we build and make.

\section{ENDNOTES}

1 Doung Anwar Jahangeer and Nathaniel Stern. Skype Interview (Milwaukee, WI and Durban, South Africa, May 22 2015)

2 Oscar Hemer. Fiction and Truth in Transition: Writing the Present Past in South Africa and Argentina (Münster, Germany: LIT Verlag, 2012), 100-101.

3 Kate-Lyn Moore. "A Long City Walk to Exhilaration." Cue. http://cue.ru.ac.za.

4 See, for example, John David Dewsbury. "Affective habit ecologies: Material dispositions and immanent inhabitations." Performance Research 17, no 4 (2012): 74-82

5 Sara Wilson McKay. "The Space Between: Intersubjective Possibilities of Transparency and Vulnerability in Art Education." Journal of Social Theory in Art Education 28/29 (2009): 56-74, p 56

6 T. Gregory Garvey. "The Value of Opacity: A Bakhtinian Analysis of Habermas's Discourse Ethics." Philosophy and Rhetoric 33, no 4 (2000): 370-90, p 382.

7 Mikhail Bakhtin. The Dialogic Imagination: Four Essays. Edited by Michael Holquist. Translated by Caryl Emerson and Michael Holquist. Austin: University of Texas Press (1981), p 296.

8 Garvey, 382-3, 371, 370, 382.

9 McKay, 57, 69, 60, 72, 60 .

10 Brené Brown. "The Power of Vulnerability." TED: Ideas Worth Spreading. June. www.ted.com (2010, Accessed May 30, 2017).

11 Michel de Certeau. "Walking in the City." The Practice of Everyday Life, Berkeley (1984): University of California Press, 91-110 (via the introduction, p. xvii).

12 Reinhold Martin. Mediations: Aesthetics, Politics, and the City. Minneapolis (2014): University of Minnesota Press, pp. 3,32. 